\title{
Urinary Total Polyamines Levels in Estrous Cycle and during Pregnancy in Female Rats
}

\author{
Ryuzo TORII and Nakaaki OHSAWA* \\ Institute for Experimental Animals, Shiga University of Medical Science, Ohtsu, \\ Shiga 520-21, Japan and *Third Department of Internal Medicine, Faculty \\ of Medicine, University of Tokyo, Hongo, Tokyo 113.
}

(Received 2 February 1988/Accepted 27 May 1988)

\begin{abstract}
Urinary total polyamines; putrescine, spermidine and cadaverine, levels were determined in the estrous cycle and during the pregnancy in female Wistar rats. Urinary total polyamines level in 12 estrous cycles in 4 female rats revealed the definite cyclic changes, showing high levels at estrous and low levels at diestrous stage. After the ovariectomy those cyclic changes disappeared. Urinary total polyamines levels were constantly low during the first half of the pregnancy of 8 female rats, whereas the levels increase abruptly from 10 days before parturition. After fetusectomy at 15th and 17th days of the pregnancy, those levels decreased gradually. These data suggested that the urinary total polyamines levels were closely related with the pituitary-ovarian function and the growth of fetus of rats.
\end{abstract}

\section{ラットの性周期および妊娠期における}

尿中総ポリアミン值の動態

鳥居隆三·大沢仲昭*

滋賀医科大学医学部付属動物実験施設

*東京大学医学部第三内科

ポリアミンは, 細胞の構成成分として植物を含むあら ゆる生命細胞に普遍的に存在する生体内アミンとして古 くから知られているが，1971年 Russell らが悪性腫瘍患 者の尿中のポリアミン量が健康人に比べ高值を示すとと を報告[13]して以来, 最近では腫渲マーカーの一つとし て注目を浴びてきている。さらに，てのポリアミンは， 多岐にわたる生物活性を有し, とくに細胞分裂, 核酸合 成, 蛋白合成に大きく関与している $[5,11]$ ことら,
腫㻤マーカーとしての意義にとどまらず, 細胞増殖因子 として各種生理・生体機能をうかがう指標の一つになる ことが考えられる。しかしながら，各種実験動物の生理 的変化に伴うポリアミンの動態は, 測定法が高速液体ク ロマトグラフィー (High Performance Liquid Chromatography； HPLC) 法, アミノ酸分析法, ガスクロ マトグラフィー法など, 煩雑でルーチンに使用すること が困難であったため，いまだ十分な成績が得られていな 
い。そこで今回，我々が開発した簡便な酵素法 $[9]$ 亿よ りラットの性周期および妊娠期の尿中総ポリアミンの測 定を行い，生理・生体機能をうかがう指標としてのポリ アミンの意義，有用性について検討を加えた。

用いたラットは, Jcl：Wistar の17週秢メスで, 温度 $23 \pm 11^{\circ} \mathrm{C}$, 湿度 $50 \pm 5 \%$, 午前 8 時点灯の 12 時間然明の飼 育室にて，オートクレーブ咸菌飼料 [CE-2，日本クレ ア秼了および給水瓶により水を与えたラット用代謝ケ一 ジ内で飼育した。尿は，アジ化ナトリウムをあらかじす 入れた容器内 $(0.01 \% / 24$ 時間尿) に，24時閒尿として 午前 8 時に採取した後, 測定に供するまで $-20^{\circ} \mathrm{C}$ 亿て保 存した。な打性周期の判定は, 凌垢像の観察によった。 すなわち，午前 8 時に 24 時間尿を採取する際同時に寚垢 像を採取, 観察し, 多数の角化細胞が認如らたた時採取 した尿を発情期の尿とした。一方，妊娠期においては， オスと一夜同居後精子が確認された日を奸娠 day 0 と した。尿中のポリアミンは, 我々の開発した方法〔「ポ リアミン・テストーエンザイム」キット, 徳山曹達秼了 を用いて, プトレッシン, スペルミジン, カダベリンの 総㫣として測定し，尿中クレアチニン $[1]$ 補正を行い求 めた。

まず，本キットがラット尿中のポリアミン測定に用い ることができるか否か検討すべく，HPLC 法と醉素法 を用いる本キットとによる測定值の比較を行った。なお HPLC 法は, Kubota ら[9]の方法を一部改変した方 法により行った。その結果, Fig.1 に示すように HPLC 法と本キット（酵素法）との相関係数は，0.999を示し 有意な相関がみられたことから，䣼素法を用いる本キッ トがラット尿中のポリアミン測定に用いることができ ることが分かった。また本キットによる変動係数は, inter-assay $1.2 \%$, intra-assay $2.3 \%$ であった。

性周期における尿中総ポリアミンの動態は, Fig. 2 に 示したように 4 匹のラットのいずれにも，発情期に高值 （135 209 nmol/mg creatinine）を示し, 発情休止期に 低值（71 112 nmol/mg creatinine）を示す明瞭な性周 期内変動がみられた。さらに，これらのラットをネンブ タール麻酥下にて両側の卵巣を摘除したところ周期性の 変動の消失を認めた。これらの成績は，尿中ポリアミン が，下垂体一卵巣機能と密接な関連を有することを示し ている。すなわち, 発情前期には FSH, LH のゴナド トロピンおよびエストロゲンの分泌が高まり $[15,16]$, これに伴い有核上皮細胞, 角化上皮細胞が增加すること が知られている。一方, ポリアミンの生合成過程におけ る律速酵素であるオルニチン脱炭酸酵素 (ornithine

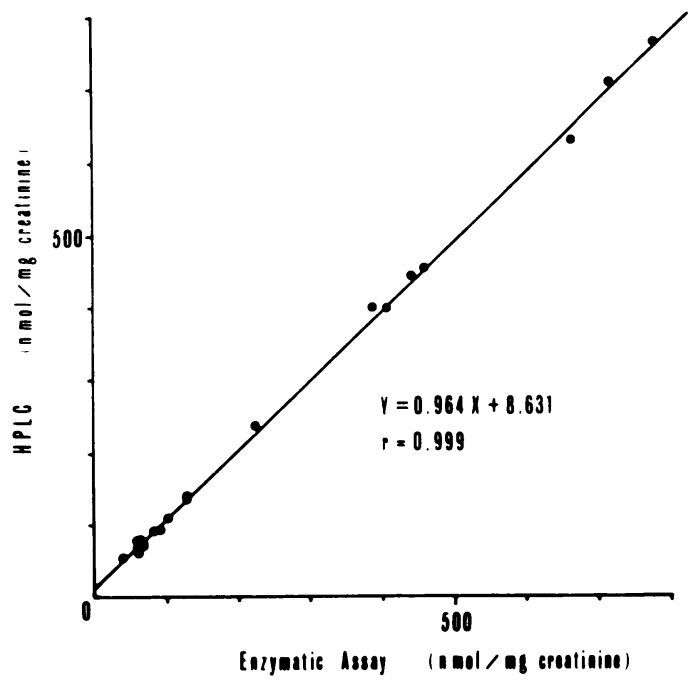

Fig. 1. Correlation between the enzymatic assay and HPLC assay of rat urinary total polyamines

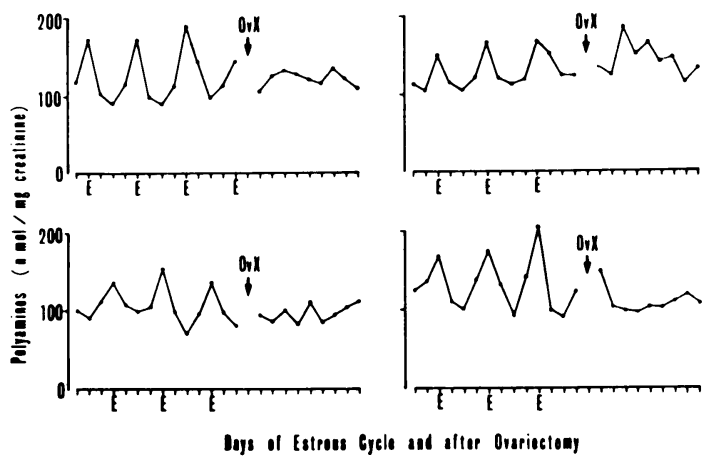

Fig. 2. Changes of urinary total polyamines levels during estrous cycle and after ovariectomy (OvX) in four female Wistar rats. E shows estrus.

decarboxylase: ODC) は,ゴナドトロピン，エストロ ゲン, アンドロゲン等のホルモンによって活性化される ことが知られ $[3,7,8,11]$, 事実ラットの性周期にお ける卵巣内の ODC 活性は, 発情期に高い值を示すこ之 が報告されている $[3,8]$ 。これらのことから発情期にみ られた尿中総ポリアミン值の增加は, 下垂体一卵巣系の 性ホルモンの上昇に伴い卵巣内の ODC 活性が上昇した ことによると考元られる。一方, 性周期内の摄餌量, 摄 水量抢よび尿量と尿中総ポリアミン值との関連性につい てみると, 摄慨量は性周期を通じてほとんど変化はなく, また摄水量および尿量はわずかに変動するものの性周期 に伴う変動は認められなかった。これらのととから性周 


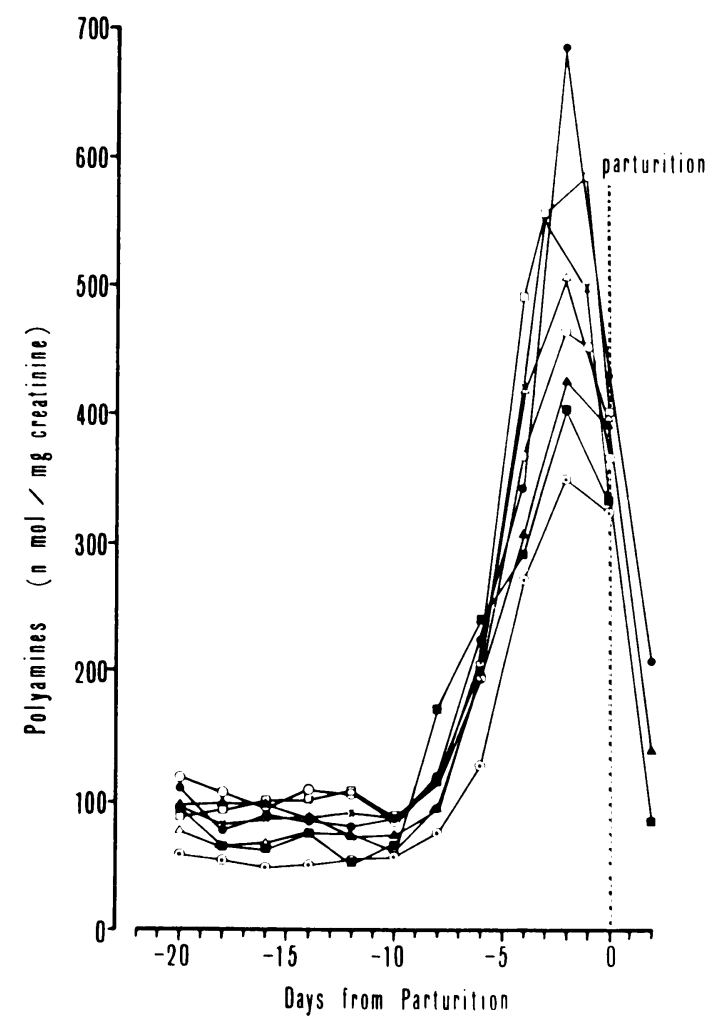

Fig. 3. Changes of urinary polyamines levels during pregnancy in eight female Wistar rats

期内の尿中総ポリアミン值の変動は, 掑餌量, 摄水量拉 よび尿量の変化に伴うものではなく，下垂体一卵巣機能 に密接に関連しその変化に伴って変動を示すことから, 下垂体一卵巣機能を反映する一つの指標になり得ること が示唆された。

次に，妊娠期における尿中総ポリアミン值の動態につ き検討したところ. Fig.3に示すように 8 匹のラットにお いていずれも分婏10日前頃まではその動態にほとんど変 化がなく低值（50〜120 nmol $/ \mathrm{mg}$ creatinine）を示して いたがその後急激な増加を示し，分娩 1 〜 月前に最高 值（350〜690 nmol $/ \mathrm{mg}$ creatinine）に達した後减少し 分娩後には低值に至った。このような妊娠後期にみられ る㽷中総ポリアミン值の急激な増加をもたらす要因につ いて, まず胎仔の発育之の関連につき検討した。妊娠 10 日目から 2 日間隔で 21 日目までの妊娠ラット各 5 匹計35 匹を用いて各々ネンブタール麻酥下にて開腹し子宫を摘 出した後, 胎仔, 胎盤书よびその他の胎仔付属物の重量 の推移を検討した。なお，妊娠10日目上12日目について

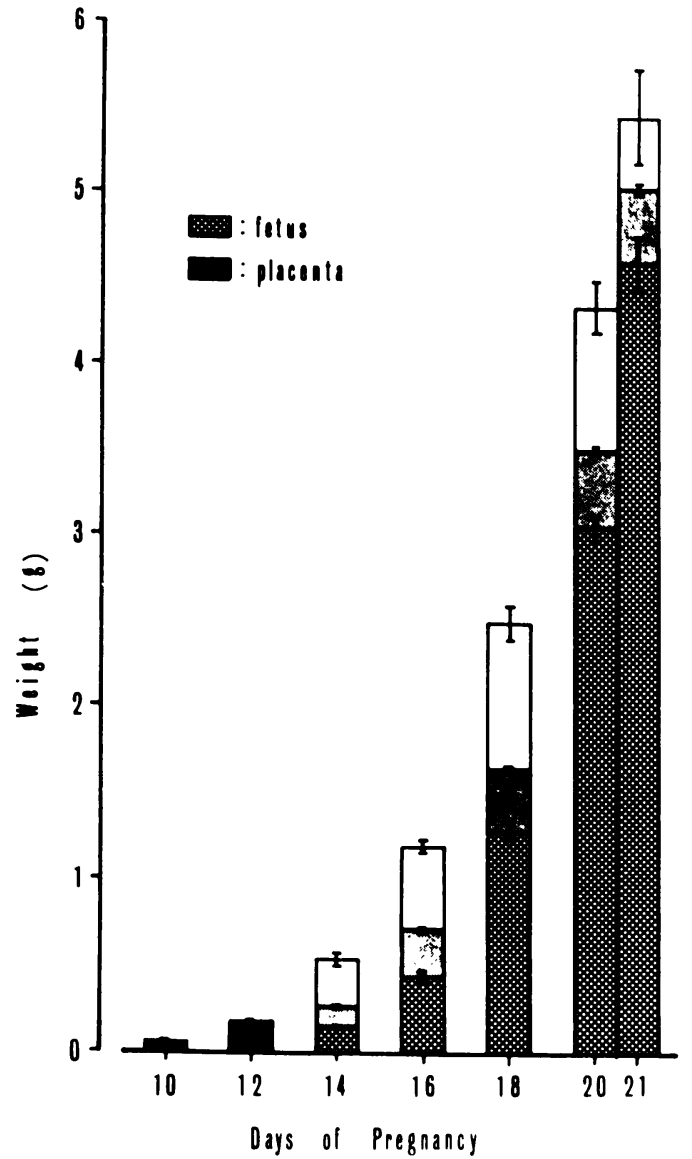

Fig. 4. Changes of weight of fetus, placenta and whole weight including fetus, placenta, membranes, fluids and others during pregnancy in female Wistaa rats. Each value represents the mean \pm SD of 59-67 samples. The value at 10 th and 12th days of pregnancy represent the mean $\pm \mathrm{SD}$ of whole weight.

は胎仔と胎盤の分離が十分に行えなかったため総重量之 して測定した。その結果, Fig.4に示したように胎仔, 胎 盤求よびその他の胎仔の付属物の重量は妊娠14日目以降 急激な增加を示し，妊娠21日目には14日目に比べ胎盤重 冒が約 4 倍の増加を示したのに比して胎仔重量は約30倍 もの增加となっていた。そこで次に尿中ポリアミン值の 急激な増加がみられる妊娠15日目と17日目においてネン ブタール妳酶下にて開腹後胎仔のみの全摘出を武みたと ころ,Fig.5に示すように示中ポリアミン值は摘出後速や かに減少を示した。これらの成績より，妊娠期における 尿中ポリアミン值は胎仔の発育に大きく関連しているこ 


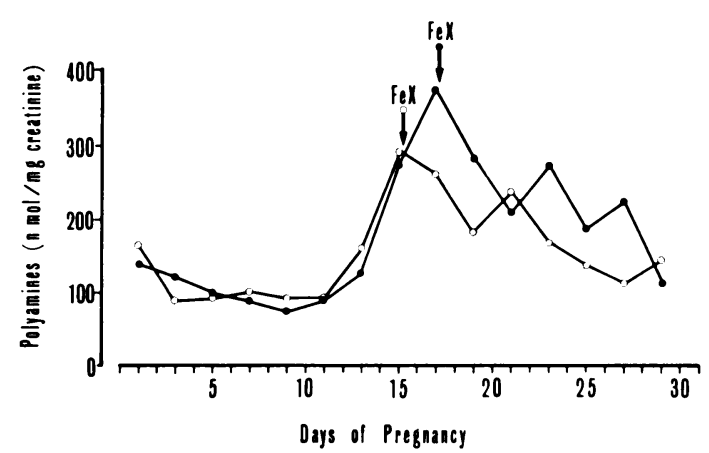

Fig. 5. Changes of urinary total polyamines levels before and after fetusectomy $(\mathrm{FeX})$ in two pregnant female Wistar rats

\section{とがうかがわれた。}

ところで，ラットの妊娠期の性ホルモンの動態ではプ ロゲステロンは妊娠12〜19日目にわずかに堌加した後減 少を示し, また LH, FSH およびエストロゲンは妊娠 20日目ごろにわずかな增加を見るにとよ゙まっている[10, 11]。しかし卵巣内の ODC 活性は妊娠10日目頃までは 低い值を示すが胎盤形成が始まる12日目頃から急激な増 加がみられている[3]。乙れらのてとから，妊娠後期に みられた尿中総ポリアミン值の急激な增加は, 母体の卵 巣機能の克進とともに胎仔の急激な発育を示していると 考えられる。なお，妊娠期における尿中総ポリアミン值 と摄慨量，摄水量および尿量との関連を見ると，摄餌量 は妊娠期を通じてほとんど変化はなく，また摄水量およ び尿量は妊娠後半に漸増をみるにとどまっている。これ らのことから, 妊娠期の尿中総ポリアミン值は, 摄餌量, 摄水量打よび尿量の変化に伴うむのではなく, 胎仔一胎 盤機能に密接に関連しているあの之考えられる。一方七 トにおいては妊娠後期プロゲステロンやエストロゲンが 急激に増加する[17]のに対して尿中ポリアミンの増加は 漸増を示す程度にとどまっている $[6]$ 。すなわち, 妊娠 期における尿中ポリアミンは母体機能の元進とそれに伴 う胎仔の急激な発育に密接な関連があり, 多胎動物であ りしかも妊娠期間の短いラットにおいてはヒトに比へてて その増加が顕著にあらわれたものと考えられる。

以上ラットの性周期および妊娠期における尿中総ポリ アミン值の動態につき検討した結果, 下垂体一卵巣 機 能, 胎仔一母体機能および胎仔の発育などをうかがうこ とのできる指標としてその有用性が明らかとなった。ま た，尿を測定材料として用いることから採血の困難な小 動物に扣いて採血, 保定などの外的刺激によるストレス
を与えることなく長期にわたって生理・生体機能を把握 することができ，しかも簡易化された再現性の高い酵素 法によって测定できることから実際の測定時間も約 2 時 間以内で行うことができるなどの利点を有している。今 後㽷中ポリアミンは腫湯マーカーとしての意義にとよ゙ま るだけでなく，動物の発癌実験 $[2,14]$, 制癌剤のスク リーニングなどをはじめとする腫晹マーカーとしての意 義はもとより, 各種疾患 $[2]$ 抢よび各種の生理・生体機 能[4]をうかがうことのできる，しかもルーチンに用い ることのできる新しい指標になり得るものと考えられる。

要 約

ラットの性周期および妊娠期における尿中総ポリアミ ン值（プトレッシン, スペルミジン, カダベリン）の動 態につき検討を行った。その結果, 尿中総ポリアミン值 は性周期においては発情期に高值を発情休止期に低值を 示す明瞭な性周期内変動が認められ, さらに卯䉾摘除に より周期性変動が消失した。一方, 妊娠期においては妊 娠後期に急激な増加がみられたがこの変化は胎仔重量の 推移と近似し，また胎仔を摘出することにより減少を示 した。これらの成績より, 㽷中総ポリアミン值は下垂体 一卵栄機能および胎仔一母体機能に密接に関連している ことが明らかとなり, 尿中総ポリアミン值は生殖生理機 能を示す指標の一つとして有用であることが示唆された。

最後に本研究に多大のご協力を頂いた石橋国夫氏, 並びに 「ポリアミン・テストーエンザイム」キットの御提供, HPLC

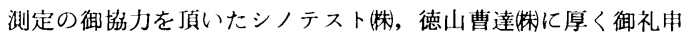
し上げます。

\section{文献}

[1] Folin, O. (1904). Z. Physiol. Chem., 41, 223-242.

[2] 藤田啓介・永津俊治・新保 寛 (1981). 蛋白質 - 核 酸 酵素, 26, 1884-1894.

[3] Guha, S. K. and Janne, J. (1976), Acta Endocr. 81, 793-800.

［4］岩崎裕治・高木 康・五味邦英 - 石井 暢 (1984). 臨床 病理, 59, 89-96.

[5] Janne, J., Poso, H., and Raina, A. (1978). Biochim. Biophy. Acta, 473, 241-293.

[6] 加来隆一・我妻 䍌 (1984). 臨床病理, 59, 69-76.

[ 7 ] Kaye, A. M., Icekson, I., Lamprecht, S. A., Gruss, A., Tsafriri, A., and Lindner, H. R. (1973). Biochemistry, 12, 3072-3076.

[8] Kobayashi, Y., Kupelian, J., and Maudsley, D. V. (1971). Science, 172, 379-380.

[9] Kubota, S., Okada, M., Imahori, K., and Ohsawa, 
N. (1983). Cancer Res., 43, 2363-2367.

[10] Labhsetwar, A. P. and Watson, D. J. (1974). Biol. Reprod., 10, 103-110.

[11] Msudsley, D. V. (1979). Biochem. Pharmacol., 28, 153-161.

[12] Morishige, W. K., Pepe, G. J., and Rothchild, I. (1973). Endocrinology, 92, 1527-1530.

[13] Russell, D. H. (1971). Nature New Biol., 233, 144145.
[14] Seiler, N., Graham, A., and Bartholeyns, J. (1981). Cancer Res., 41, 1472-1573.

[15] Shaikh, A. A. (1971). Biol. Reprod., 5, 297-307.

[16] Taya, K. and Igarashi, M. (1973). Endocr. Japon., 20, 199-205.

[17] Tulchinsky, D., Hobel, C. J., Yeager, E., and Marshall, J. R. (1972). Am. J. Obstet. Gynecol., 117, 884-893. 